\title{
変調型光コムを用いた精密距離計測器
}

\author{
今井一宏 ${ }^{1}$, 興梠 元伸 $^{1}$, 寺田 聡一 $^{2}$
}

${ }^{1}$ (株)光コム（†226-8510 神奈川県横浜市緑区長津田町4259-3 中小機構・東工大横浜ベンチャープラザE206号室） 2独立行政法人 産業技術総合研究所（†305-8563 茨城県つくば市梅園1-1-1つくば中央第3）

\section{Precise Absolute Distance Meter Using EO-Modulator-Based Optical Frequency Comb}

\author{
Kazuhiro IMAI, ${ }^{1}$ Motonobu KOUROGI,${ }^{1}$ and Souichi TERADA ${ }^{2}$ \\ ${ }^{1}$ Optical Comb, Inc., YVP E206, 4259-3 Nagatsuta-cho, Midori-ku, Yokohama, Kanagawa 226-8510 \\ ${ }^{2}$ Advanced Industrial Science and Technology, AIST Tsukuba Central3, 1-1-1 Umezono, Tsukuba, Ibaraki 305-8563
}

(Received May 30, 2014)

\begin{abstract}
Using two electro-optic modulator-based optical frequency comb sources, we demonstrate an optical frequency comb interferometer that enables rapid and precise measurement of over long distances. $500 \mathrm{kHz}$ is the repetition rate of the relative measurement of a 6-mm ambiguity range. The repetition rate of an absolute distance measurement is about $15 \mathrm{~Hz}$ with switching modulation frequencies. The optical frequency comb interferometer yields $0.4-\mu \mathrm{m}$ precision at $5.2 \mathrm{~m}$ in $2 \mu \mathrm{s}$. The improved precision exceeded $30 \mathrm{~nm}$ in $1 \mathrm{~ms}$.
\end{abstract}

Key Words: Optical frequency comb, Interferometer, Distance measurement

1.はじめに

光コムは, 一定周波数間隔で狭いスペクトル線幅の光 が多数並んでおり, 広いスペクトル包絡線幅を有する光 である ${ }^{1)}$ 。一本の線スペクトルで決まる長い可干渉距離 と全体のスペクトル幅で決まる短い可干渉距離が混在し ているため, 距離計に応用すると長距離と高分解能とい う相反する性能を両立する可能性を持っている.

一般にレーザー光路の絶対距離は，飛行時間法のよう にパルスや正弦波など強度変調を受けた光が測定対象に あたって戻ってくるまでの遅延時間から計測される。そ の分解能はどこまで高い周波数成分を遅延時間計測に利 用できるかで決まる。 ところが発振器, 変調器, 検出器 など素子の動作周波数の上限は〜数十 $\mathrm{GHz}$ であり, 光強 度の直接検出では周波数を上げて分解能を上げることは 容易ではない，計測距離数十メートル以上の実用的な レーザー距離計で得られる分解能は周期誤差も考慮に入 れると比較的性能の高いもので50〜 $100 \mu \mathrm{m}$ 程度であ

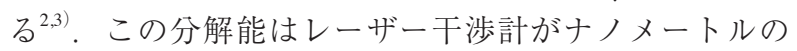
分解能を達成できることと比較して低い.

光コム干渉は, 測定対象に照射される物体光と基準と なる参照光がそれぞれ光コムであり，物体光と参照光の 周波数が一対一に対応した多波長干渉のことを表 す ${ }^{4-6)}$. 光コム干渉はピコ秒の時間をマイクロ秒に拡大 する特徵があるため, 素子の動作周波数の制約を受けず
に飛行時間計測の分解能を高めることができる.

変調型光コムは電気光学変調によるサイドバンドから なる光コムであって，その周波数と位相は入力された レーザー光と変調信号だけで決まる。我々は, 中心周波 数とモード間隔を独立に調整できる変調型光コムの制御 性の高さに着目し, 変調型光コムの干涉を利用する高精 度距離計, 形状計測機の開発を進めている ${ }^{4,7)}$ 。モード 同期レーザー型のコム光源を二台使用しても光コムの 1 本を選択して互いに光位相同期をかければ同様な干涉計 を組むことが可能であるが(6)，変調型光コム発生器を使 用すると光位相同期なしに共通の狭スペクトル線幅レー ザーに由来する長い可干渉距離をとれる利点がある。計 測の繰り返しが高く，高速な距離計として液体金属の厚 み計測へ応用された例もある ${ }^{8)}$ 。本稿では，我々が開発 した光コム干渉計の原理と距離計, 形状計測機への応用 と関連する研究の動向について報告する。

\section{2. 光コム干渉計}

\section{1 光コム発生器}

Fig. 1は, 我々が光コム発生器と呼ぶファブリペロー 電気光学变調器の概念図である ${ }^{1,9)}$. 光位相変調器が ファブリペロー共振器に挿入された構造である. 入力は 単一周波数 $v$ のレザー光である. 入力光の周波数を共 振器透過モードの一つに合わせ, 自由スペクトルレンジ 


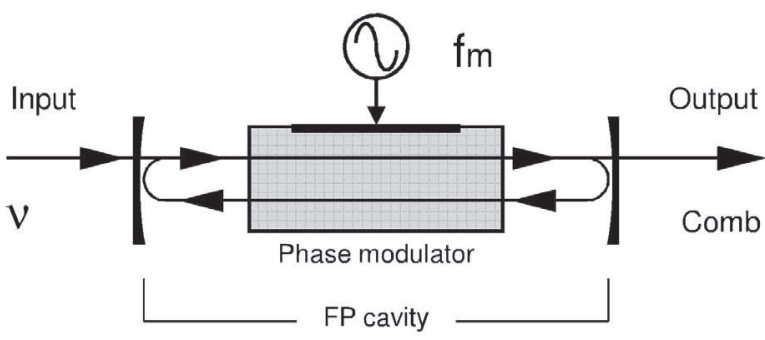

Fig. 1 Schematic of optical frequency comb generator (OFCG) using Fabry-Perot electro-optic modulator.

(Free Spectral Range: FSR)の整数倍に一致する周波数 $f_{\mathrm{m}}$ の電気信号を位相変調器に与えると, 変調された光が共 振器を往復する周期と電気信号の周期が一致する。被変 調光は共振器を多重往復する間, 毎回同じ位相で電気光 学変調を受けるため, 一台の変調器で数十台の位相変調 器を直列に接続するのと同等の効果が得られる。通常の 駆動レベルでは数本しか発生しないサイドバンドが数百 本発生して中心周波数 $v$, 間隔 $f_{\mathrm{m}}$ のコム状出力となる. 時間的には繰り返し周波数 $f_{\mathrm{m}}$ の光パルスとなる.

\section{2 光コム干渉計の構成}

光コム干渉では一つの干渉信号に多数モードの位相情 報が混在するため，それらの分離が課題となる．Fig. 2 は我々が開発した光コム干渉計の構成例である。駆動周 波数の異なる2台の光コム発生器 (OFCG1, OFCG2) と周 波数シフタ(AOFS) を使用して干涉信号の周波数軸で モードの分離を行うことが特徴である. 光コム発生器の 入力光源は発振波長は $1554.94 \mathrm{~nm}$, 出力約 $20 \mathrm{~mW}$, スペ クトル線幅 $15 \mathrm{kHz}$ 以下の単一周波数発振レーザーであ る.レーザーの出力光は第一のビームスプリッタ (BS1) で分割されてOFCG1, OFCG2へ入力される。 それぞれ 測定対象に照射される物体光と参照面に照射される参照 光を出力する. AOFSはOFCG2への入力光の周波数を $40 \mathrm{MHz}\left(f_{\mathrm{a}}\right)$ ずらし, 干渉信号の中心周波数にオフセット を与える。

OFCG1, OFCG2は $\mathrm{LiNbO}_{3}$ 光導波路型の光コム発生器 で，光ファイバピグテイル付のモジュールになってい $3^{10)}$. FSRは $25 \mathrm{GHz}$ 帯の変調周波数に合わせて $2.5 \mathrm{GHz}$ に調整されている. 変調周波数には共振器のフィネスと 変調指数で許容される幅があり，25２5.0105 GHzまで の変調周波数に対応している．また共振周波数と光コム 周波数を一致させるため電子回路による低速な共振器制 御を行っている ${ }^{11)}$. 光コム出力は, 光増幅器, 可変減衰 器により物体光〜 $10 \mathrm{~mW}$, 参照光 $3 \mathrm{~mW}$ 程度に調整され ている. 入力レーザー光源からOFCG1, OFCG2の出力 までの光学系は光ファイバで接続されており, 幅19イン チ高さ $4 \mathrm{U}($ 約 $18 \mathrm{~cm})$ の一筐体に収納されている。駆動周 波数は外部のPCや筐体フロントパネルのボタンから変 更できるようになっている.

物体光と参照光を第一の偏光ビームスプリッ夕 (PBS1) で直交した偏光で重ねてからそれぞれ出力の一 部を第二のビームスプリッタ (BS2)で分岐して偏光素子 (POL) で偏光を調整してから参照信号を出力する差動光

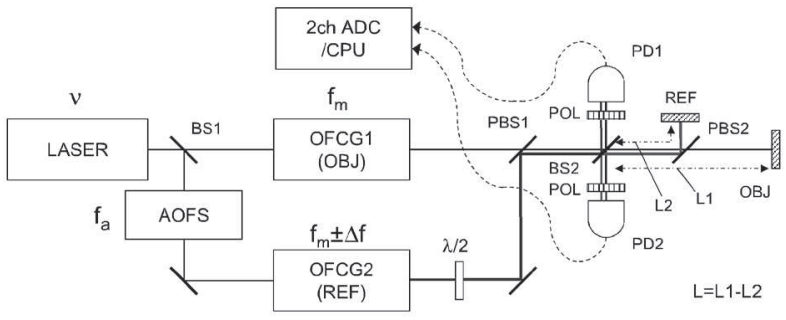

Fig. 2 Schematic of the optical frequency comb interferometer. LASER: laser light source, AOFS: acousto-optic frequency shifter, OFCG1 (OBJ): object OFCG, OFCG2 (REF): reference OFCG, REF: reference mirror, OBJ: measurement target, PD1: balanced photo receiver 1, PD2: balanced photo receiver 2, 2ch ADC: 2 channel analog-todigital converter, CPU: signal processor, BS1, BS2: beamsplitters, PBS1, PBS2: polarizing beamsplitters, POL: polarization control, $\lambda / 2$ : half wave plate, $v$ : laser frequency $(\sim 193 \mathrm{THz}), f_{\mathrm{a}}$ : $40 \mathrm{MHz}, f_{\mathrm{m}}$ : modulation frequency for object light, $f_{\mathrm{m}} \pm \Delta f$ : modulation frequency for reference light, $L$ : distance between the OBJ and the REF ( $L=L 1-$ L2).

検出器1(PD1) に入力する. PD1へ向かわず, BS2を通過 した物体光，参照光はその先の第二の偏光ビームスプ リッタ (PBS2)で物体光は測定対象へ, 参照光は参照面 へ向けて分離される。それぞれ反射された光はPD1と同 じ構成を有し測定信号を出力する差動光検出器2(PD2) に入力される. PD $1, \mathrm{PD} 2$ の帯域は1〜100 MHz程度であ る. 干渉計は超高速光コヒーレンストモグラフィーとし て提案された干渉計 ${ }^{4}$ を二重化した構造である. OFCG1，OFCG2を除いた構成の機能は一般的なレー ザー干渉計と同等である。

PD1, PD2から出力された干渉信号は同軸ケーブルで $\mathrm{AD}$ 変換器に入力され，2チャンネル同時にサンプリング される. 光コム駆動周波数やサンプリング周波数など光 コム干渉計内部のすべての周波数は共通の恒温槽付水晶 発振器 $(\mathrm{OCXO})$ に同期されている. 周波数の長期安定度

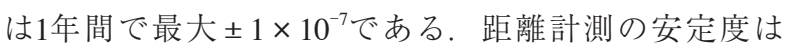
OCXO周波数の安定度に一致する.

測定距離が $f_{\mathrm{m}}$ の半波長を超えると物体光の周期性によ りその半波長の整数倍の距離が不明となって一義的に距 離を求められない.その半波長相当の距離はambiguity range (多義性距離, 以下 $L_{\mathrm{a}}$ と表記) などと呼ばれる。 $f_{\mathrm{m}}=25 \mathrm{GHz}$ の場合, $L_{\mathrm{a}}\left(=c / 2 f_{\mathrm{m}}, c\right.$ : 光速) は約 $6 \mathrm{~mm}$ であ る. Fig. 2の干渉計では $10 \mathrm{MHz}$ 異なる $f_{\mathrm{m}}$ の計測を組み合 わせることにより $L_{\mathrm{a}}$ より長い絶対距離を測定するような 仕組みになっている，駆動周波数の差 $\Delta f$ 絶対值は常に $500 \mathrm{kHz}$ である。

\section{3 光コム干渉の周波数関係}

Fig. 3は光コム干涉の周波数関係を表す．Nは光コム の中心周波数から数えたモード番号である。物体光と参 照光のN次モード周波数はそれぞれ $v+\mathrm{N} f_{\mathrm{m}}, \quad v+f_{\mathrm{a}}+\mathrm{N}$ $\left(f_{\mathrm{m}}+\Delta f\right)$ である. N次モード間干渉信号の周波数は $f_{\mathrm{m}}$ に 関係なく $f_{\mathrm{a}}+\mathrm{N} \Delta f$ であり，40 MHzを中心とする $500 \mathrm{kHz}$ 間 


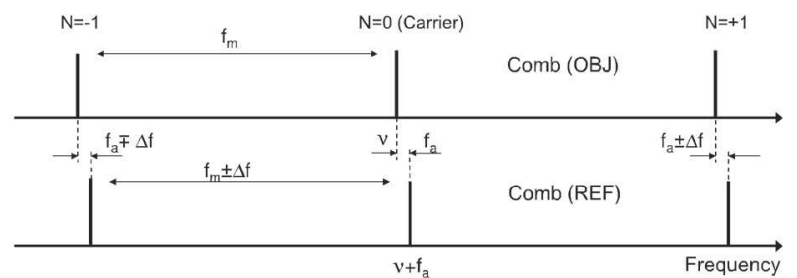

Fig. 3 The frequency relation between the object light and the reference light. Comb (OBJ): object light, Comb (REF): reference light, $\mathrm{N}$ : sideband order number, $v$ : input laser frequeny, $f_{\mathrm{a}}$ : off set frequency, $f_{\mathrm{m}}$ : comb frequency separation for the object light, $f_{\mathrm{m}}+\Delta f$ : comb frequency separation for the reference light.

隔のコム状スペクトルとなる。その他の干渉の組み合わ せは光検出器の帯域外となる。参照光と物体光の位相差 で駆動される干渉信号には参照光に対する物体光の位相 遅れ情報がすべて含まれる，検出系の帯域に合わせ，入 力波長を中心にスペクトル幅1～ $2 \mathrm{THz}$ 残す急峻な特 性の光フィルタで干渉信号のエイリアスの要因となりう る高次モードを除去している. 物体光の周波数間隔 $f_{\mathrm{m}}$ が $25 \mathrm{GHz}$ の場合, \pm 20 次までの光コム干渉は光スペクトル 幅1 THzの位相，振幅情報取得と等価になる。経験的に は数百GHz以上の光スペクトル幅があれば $1 \mu \mathrm{m}$ 程度の分 解能が得られる。

\section{4 干渉信号波形}

光コム干渉では時間的に $\Delta f$ の周期 $2 \mu s に 1$ 回の割合で 物体光と参照光の光パルスの重なりが起こる. 光パルス が重なり合う時間だけ干渉信号が生成されるためパルス 状の信号になる. Fig. 4 (a) はPD1から出力される参照信 号波形, (b) はPD2から出力される測定信号波形であ る。干渉信号はそれぞれ40 MHzを搬送波とする2 $\mu \mathrm{s} の$ 周期の包絡線パルスである. 物体光が BS2 と測定対象を 往復する遅延時間と参照光がBS2 と参照鏡を往復する遅 延時間の差Tのため, 測定信号パルスと参照信号パルス の発生時刻には時間差が生じる。 $f_{\mathrm{m}}=25 \mathrm{GHz}$ の場合, $2 \mu \mathrm{s}$ は $L_{\mathrm{a}}$ の一区間を物体光が往復する時間 $40 \mathrm{ps}$ に相当 し，干渉信号はTを50,000倍に拡大して観測させる．測

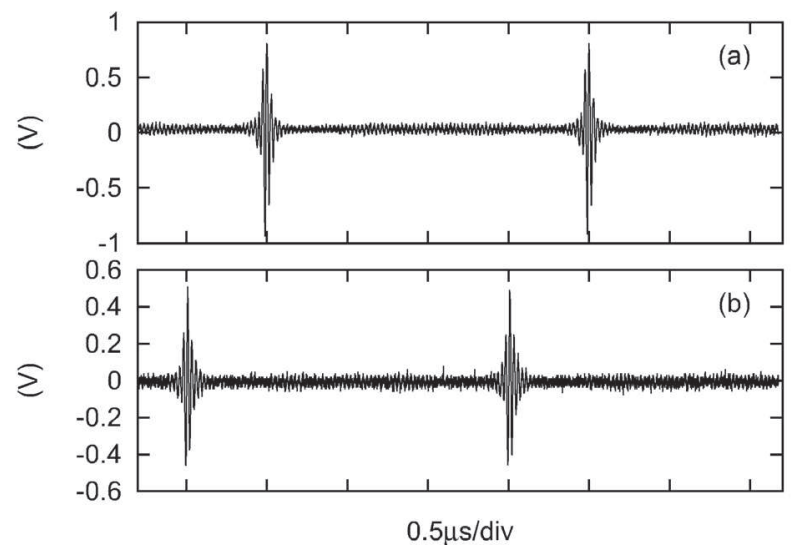

Fig. 4 Waveforms of the interference signals. (a) PD1: reference signal, (b) PD2: object signal.
定信号パルスは原理的に入カレーザーの可干涉距離まで $6 \mathrm{~mm}$ あり $2 \mu \mathrm{s}$ の割合で時刻を変えながら発生を続け る。周期信号である参照信号と測定信号の間で信号パル スの位相差を求めることにより共通に含まれる遅延時間 差は相殺されてTが求められる.

\section{5 信号処理}

$\mathrm{AD}$ 変換器で参照信号と測定信号の一周期をサンプリ ングして周波数解析を実行する。参照信号と測定信号の N次モード同士の位相差を計算してOFCG1, OFCG2か らBS2までの光コム生成, 伝送過程の光位相差を相殺し た後, 周波数軸で次数 1 あたりの位相差の増分を計算し て信号パルスの位相差を求める。 $L_{\mathrm{a}}$ を超える距離を算出 するため4通りの周波数設定で同じ処理を行う。それぞ れ物体光 $(\mathrm{OFCG} 1)$ と参照光 $(\mathrm{OFCG} 2)$ の変調周波数と信 号パルスの位相差の関係はTable 1の通りである。信号パ ルスの位相差は $T$ と物体光の変調周波数の積で表され る。参照信号と測定信号がそれぞれサンプリングされる までのケーブル長の差は真空中の距離換算 $1 \mathrm{~m}$ たり $20 \mu \mathrm{m}$ のフセットを計測值に与えるが, 絶対距離計算 の過程で相殺できるため省略した.

\section{6 絶対距離計算}

Table 1の\#1の位相差は, 計測する距離が $f_{\mathrm{m}}$ の半波長よ り長い場合， $\mathrm{m}$ を整数として $\phi+2 \mathrm{~m} \pi$ の形である。計算 では $\phi$ 部分だけが求められるが, 整数值虫は不明であ る。一方，\#1と\#2の差または\#3と\#4の差を計算すると $2 \pi \Delta f_{\mathrm{m}} T$ が得られる。 $\Delta f_{\mathrm{m}}=10 \mathrm{MHz}$ なので $L_{\mathrm{a}}$ は約 $15 \mathrm{~m}$ とな り,この距離までならば一義的に位相が決まる。この位 相を $f_{\mathrm{m}} / \Delta f_{\mathrm{m}}$ 倍して\#1の位相差との比較により整数 $\mathrm{m}$ 判 定する。 $\Delta f_{\mathrm{m}}$ の位相から整数 $\mathrm{m} \pm 0.1$ の精度で決定する ためには，15 mの距離を誤差 $0.6 \mathrm{~mm}$ 以内で計測できる $4 \times 10^{-5}$ の精度が必要である。相対的には $L_{\mathrm{a}}=6 \mathrm{~mm}$ を誤 差 $\pm 240 \mathrm{~nm}$ 以内で計測する精度が要求される。平均時 間を長くしても信号のスプリアスや干渉計内部の残留反 射光による周期誤差の影響が残り，静止状態で整数值か らの誤差は概ね \pm 0.15 の範囲である。誤差はレーザー光 の半波長 $(\sim 775 \mathrm{~nm})$ より小さいため, 安定化光源を入 力とすればレーザー波長の整数倍を判定することも可能 である7)

さらにTable 1の\#1と\#3の差から $2 \pi \Delta f T$ 得られる. $\Delta f$ $=500 \mathrm{kHz}$ であるから $L_{\mathrm{a}}$ は300 $\mathrm{m}$ となり，その距離までの

Table 1 Modulation frequencies and numerical expressions of the phase difference between reference signal and object signal. $f_{\mathrm{m}}=25 \mathrm{GHz}$, $\Delta f=500 \mathrm{kHz}, \Delta f_{\mathrm{m}}=10 \mathrm{MHz} . T$, Time of flight.

\begin{tabular}{ccc}
\hline$\#$ & OFCG1/OFCG2 & Signal phase difference \\
\hline 1 & $f_{\mathrm{m}} /\left(f_{\mathrm{m}}+\Delta f\right)$ & $-2 \pi f_{\mathrm{m}} T$ \\
2 & $\left(f_{\mathrm{m}}+\Delta f_{\mathrm{m}}\right) /\left(f_{\mathrm{m}}+\Delta f_{\mathrm{m}}+\Delta f\right)$ & $-2 \pi\left(f_{\mathrm{m}}+\Delta f_{\mathrm{m}}\right) T$ \\
3 & $\left(f_{\mathrm{m}}+\Delta f\right) / f_{\mathrm{m}}$ & $-2 \pi\left(f_{\mathrm{m}}+\Delta f\right) T$ \\
4 & $\left(f_{\mathrm{m}}+\Delta f_{\mathrm{m}}+\Delta f\right) /\left(f_{\mathrm{m}}+\Delta f_{\mathrm{m}}\right)$ & $-2 \pi\left(f_{\mathrm{m}}+\Delta f_{\mathrm{m}}+\Delta f\right) T$ \\
\hline
\end{tabular}


絶対距離計算が可能である. 精度 \pm 0.1 の整数值判別に 必要とされる正確さは $300 \mathrm{~m}$ の距離を誤差 $1.5 \mathrm{~m}$ 以内で計 測できる $5 \times 10^{-3}$ 程度であり， $\Delta f_{\mathrm{m}}$ の位相から整数的を決 定できる精度があれば十分である。

計測の速度は, $6 \mathrm{~mm}$ 以内の相対距離測定では $\Delta f$ に等 しく $500 \mathrm{kHz}$ である. 周波数の切り替えを要する絶対距 離測定の速度は切り替え時間と絶対距離計算時間を含め て現時点で $15 \mathrm{~Hz}$ 程度である。また，信号を切り替える 代わりに光スイッチで物体光と参照光を入れ替えて照射 する方法でも同様な計算が実行できる.

\section{3. 計測精度}

干渉信号が低速で周波数が低いことは信号処理の面で 有利であるが, 発振器の位相雑音の影響を低い周波数か ら受けやすいという性質もある。物体光を駆動するマイ クロ波の位相ゆらぎを $\phi_{0}(t)$, 参照光のそれを $\phi_{1}(t)$ とす ると信号パルスの位相差 $2 \pi f_{\mathrm{m}} T$ は

$$
\begin{aligned}
2 \pi f_{\mathrm{m}} T & =2 \pi \Delta f \Delta t+2 \mathrm{~m} \pi \\
& +\left\{\phi_{0}(t)-\phi_{0}(t+\Delta t+T)\right\} \\
& -\left\{\phi_{1}(t)-\phi_{1}(t+\Delta t)\right\}
\end{aligned}
$$

の形式で干渉信号の位相遅れ $2 \pi \Delta f \Delta t$ として計測される。 $\mathrm{m}$ は絶対距離を計算する際に必要な整数である。 $\Delta t$ は, もっとも近い参照信号パルス発生時刻から計測した測定 信号パルス発生までの時間である。右辺，二行目以降は 変調信号の位相雑音である。 $\Delta t$ や Tの増加により相関が 失われたマイクロ波の位相摇らぎが距離のばらつきとし て出力される.Tが, 光パルスが測定距離を往復する飛 行時間 $(5 \mathrm{~m} て ゙$ 約 $33 \mathrm{~ns})$ 程度の值であるのに対して $\Delta t \mid$ は, $\Delta f=500 \mathrm{kHz}$ の場合, 最大 $1 \mu \mathrm{s} に$ 達する.このため近距 離では $\Delta t は T に$ 比べてより広い周波数帯域の位相摇らぎ を計測值のばらつきとして出現させ, 計測精度の低下を

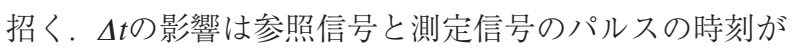
一致している条件 $|\Delta t|=0$ では少なく, 時刻差の絶対值が $|\Delta t|=1 \mu \mathrm{s}$ のきに最大となる。これは周期的な精度の 低下として観測される。2台の駆動信号の位相同期を広 帯域で行うと $\phi_{0}(t)$ と $\phi_{1}(t)$ で位相摇らぎが相殺されるた め $\Delta t$ の影響を減らすことができる.

二台の光コム発生器の駆動信号はオフセット周波数 $1 \mathrm{MHz}$ における位相雑音レベルはそれぞれ $-120 \mathrm{dBc} / \mathrm{Hz}$ 以下であるが，相対的にはー $150 \mathrm{dBc} / \mathrm{Hz}$ 以下になってお り極力 $\Delta t$ の影響を受けないように配慮されている。 Fig. 5は距離計の計測精度を表す。精度は測定周期 $2 \mu \mathrm{s}$ で連続10秒間取得した距離データから計算したアラン分 散の平方根で表示されている。（a）は距離24 mmと $27 \mathrm{~mm}$ におり精度である。 $24 \mathrm{~mm} は \Delta t=0$ の状態, $27 \mathrm{~mm}$ では $\Delta t=1 \mu \mathrm{s}$ の状態である. データの出力周期は $2 \mu \mathrm{s}$ に固定されているため, 連続する $2 \mu \mathrm{s}$ 間隔の複数 データを平均して長い周期のデータとみなした。測定時

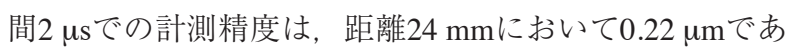

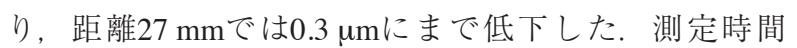
$1 \mathrm{~ms}$ の時に両者の差はなくなり $20 \mathrm{~nm}$ 以下に達した.さ
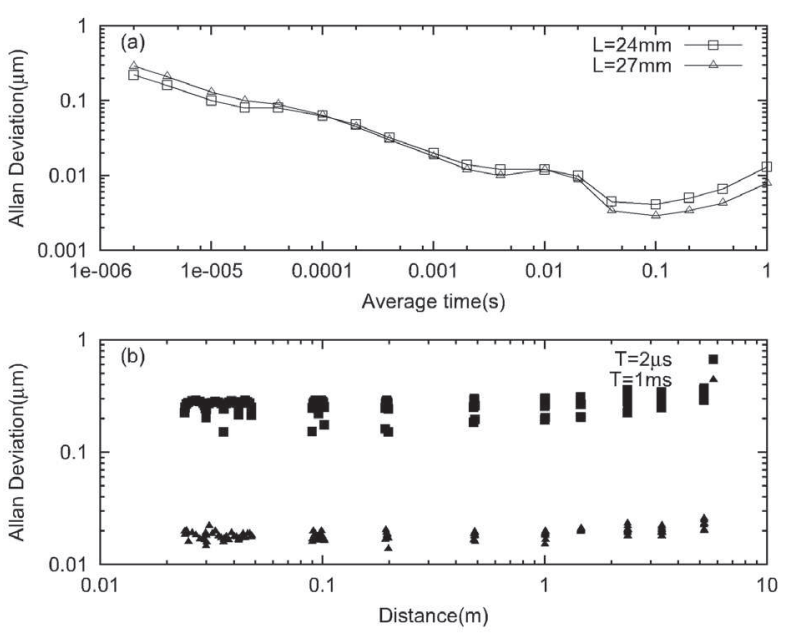

Fig. 5 Precision of the distance measurement. (a) Allan deviation versus averaging time. $\square, 24 \mathrm{~mm}$ distance; $\triangle, 27 \mathrm{~mm}$ distance. (b) Allan deviation versus distance. $\boldsymbol{\square}$, averaging time $2 \mu \mathrm{s} ; \boldsymbol{\Delta}$, averaging time $1 \mathrm{~ms}$.

らに計測時間 $0.1 \mathrm{~s} て ゙ 5 \mathrm{~nm}$ に達したが, $1 \mathrm{~s} て ゙ 10 \mathrm{~nm}$ に増加 した. $10 \mathrm{~ms} 1 \mathrm{~s}$ あたりの精度の低下傾向は評価の度に 変化があり, 測定場所の振動や空気屈折率の変動の影響 を受けていると推測している。Fig.5（b)は測定距離と 精度の関係を示している，横軸は距離, 縦軸はアラン分 散の平方根である。計測時間はロが $2 \mu \mathrm{s}, \Delta$ ム $1 \mathrm{~ms}$ であ る. 計測時の物体光の駆動周波数は $25 \mathrm{GHz}$ であり, そ の半波長 $6 \mathrm{~mm}$ の周期で分散值の極大, 極小の繰り返し が現れる特性となっている。近距離での精度は計測時間 $2 \mu \mathrm{s} て ゙ 0.2 \mu \mathrm{m}$ と $0.3 \mu \mathrm{m}$ の間, 計測時間 $1 \mathrm{~ms}$ では $20 \mathrm{~nm}$ 程度 であった。距離 $5.2 \mathrm{~m}$ でも計測時間 $2 \mu \mathrm{s}$ で $0.4 \mu \mathrm{m}$ 以下，計 測時間 $1 \mathrm{~ms}$ では30 nm以下であった。また，長距離ほど 分散值の極小值, 極大值ともに大きくなるのは, 光パル スが測定対象を往復する時間遅延Tの増大による位相雑 音の影響が距離に応じて単調増加するためである。

\section{4. 計測誤差}

光コム距離計の測定誤差を評価するため, 産業技術総 合研究所 (AIST)つくばセンターの光学トンネルで干涉 測長器との比較測定を行った。光学トンネルは気温が安 定しており，空気屈折率の影響が大きい距離測定で有利 な施設である. 光学トンネル内には全長 $100 \mathrm{~m}$ の直進ス テージが設置されており，ステージの移動距離は干渉測 長器という He-Neレーザーを光源とする干渉計で測定し ている，干涉測長器本体を固定の台座に設置し，ステー ジ上に反射鏡を設置して移動距離を測っているが，ス テージのヨーイングやピッチングの影響を低減するため に，2台の干渉測長器を用い測定している，2台のレー ザービームは水平方向に $25 \mathrm{~cm}$ 離れている。 その中心を 光コム距離計のビームで測定し, 2 台の干渉測長器の平 均值と比較する. 光コム距離計の代わりに, $\mathrm{He}-\mathrm{Ne}$ を光 源とする別の干渉測長器の校正を行った場合, 空気屈折 率が同じになるため, 測定の不確かさは1.7 $\mu \mathrm{m}$ である. 

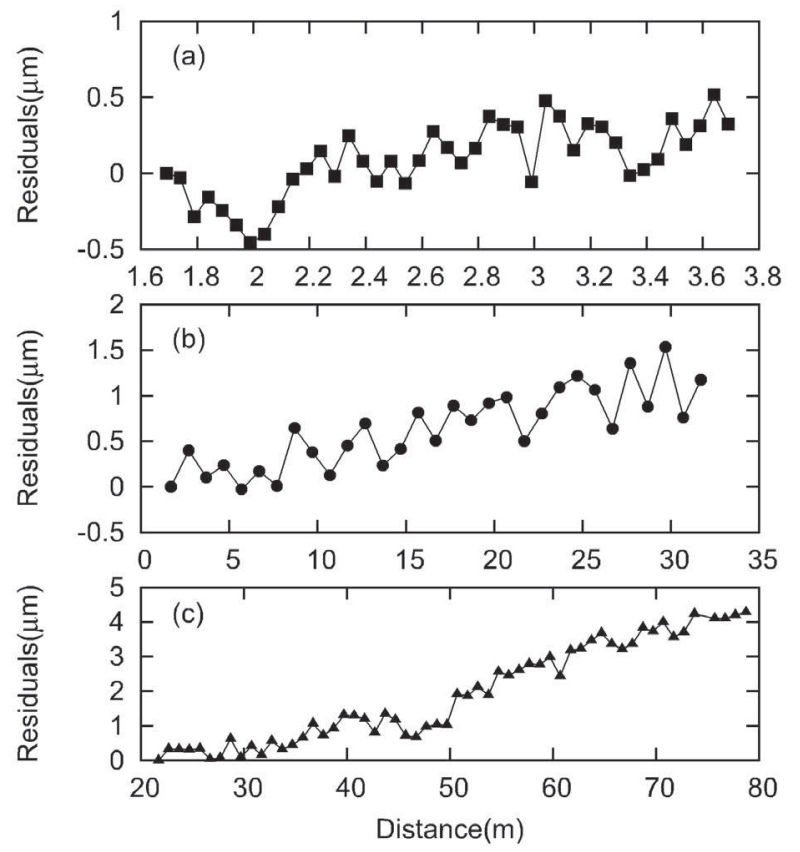

Fig. 6 Residuals of the measured distance versus truth data from c.w interferometers. The measurements were performed in the optical tunnel of the AIST. (a) $1.7 \mathrm{~m} \sim 3.7 \mathrm{~m}, 5 \mathrm{~cm}$ apart; (b) $1.7 \mathrm{~m} \sim 32 \mathrm{~m}$, $1 \mathrm{~m}$ apart; (c) $20 \mathrm{~m} \sim 80 \mathrm{~m}, 1 \mathrm{~m}$ apart.

光コム距離計ヘッドの射出ビームの直径は強度 $1 / \mathrm{e}^{2}$ の 全幅でおよそ3.6 mmである。射出ビームの設計におい て想定した距離計測範囲は5 mであるが, 約 $30 \mathrm{~m}$ までは 反射強度低下があるものの光コム距離計の設定を変えず に絶対距離計測が可能であった。PC制御でヘッド内蔵 の光減衰器を抜去すると $20 \mathrm{~m}$ から $78 \mathrm{~m}$ まで連続的に測 定できた。 $78 \mathrm{~m}$ 以上では, 極度の反射光強度低下と空 気の摇らぎが原因とみられる反射強度の大振幅変動によ り絶対距離計測が不能となった。

Fig. 6 (a)〜 (c) は3回に分けて行われた比較測定の結果 である。それぞれ (a) 距離 $1.7 〜 3.7 \mathrm{~m}$ を $5 \mathrm{~cm}$ の間隔，（b） 距離1.7〜32 mを1 mの間隔, (c) 距離 $20 \mathrm{~m} \sim 80 \mathrm{~m}$ を $1 \mathrm{~m}$ の 間隔で直進ステージを移動させた場合の干涉測長器を基 準とした光コム距離計の誤差を表している。ここでの誤 差は測定距離範囲のうちへッドから反射体までの距離が 最も近い測定点での距離計測值の差を差し引いた相対距 離の差を表している。距離1.7〜3.7 mでの誤差 は土0.5 $\mu \mathrm{m}$ 以内であり, 評価装置側の精度と比較して有 意な誤差は見られなかった。測定開始距離から終了距離 まで積算された誤差は，距離1.7〜32 mまでがおよそ $1.5 \mu \mathrm{m}$ ，距離20〜78 mまでが4 $\mu \mathrm{m}$ であった，最悪值とし

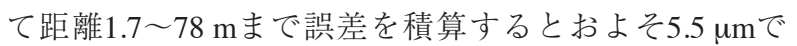
あり $0.5 \mu \mathrm{m}$ の変動を考慮しても誤差は $6 \mu \mathrm{m}$ 以内であ ると推定され，相対誤差はおよそ7 $\times 10^{-8}$ となる。周波 数カウンタにより OCXOの発振周波数の誤差は $1 \times 10^{-8}$ で あると確認されている。屈折率補正に使用した屈折率の 近似式は350～1300 $\mathrm{nm}$ で有効であるとされており， $1550 \mathrm{~nm}$ 帯における屈折率補正の精度が誤差要因の一つ と考えられる12).

\section{5. 表面形状計測}

Fig. 7は呼び段差10〜1 $1 \mu \mathrm{m}$ の段差マス夕の表面形状を 計測した結果である。焦点距離 $100 \mathrm{~mm}$ 相当の組み合わ せレンズと二次元ビームスキャナでテレセントリック $\mathrm{f}-\theta$ 光学系を組んでいる。焦点位置でのビームスポット 系は約 $60 \mu \mathrm{m}$ である。計測時間は周波数切り替えなしで 500 点 $\times 500$ 行のスキャン 1 回あたり約2秒である. Fig. 7 は10回計測の平均值を表示している. $1 \mu \mathrm{m}$ の段差も判 別できていることがわかる.1回計測でも画像処理を行 えば1 $\mu \mathrm{m}$ の段差の判別は可能であった。鏡面反射体以 外に機械加工された拡散反射面，塗装面，プラスチック などの表面形状を計測することができる。傾斜や湾曲の 大きな鏡面，多重反射を発生する半透過性を持つフィル ム, 可干渉性を低下させる多孔質などは誤差が大きい.

\section{6. 研究の動向}

二台の光コム光源の干渉を応用した距離計として他 に，周波数間隔のわずかに異なるモード同期レーザー型 のコム発生器を二台使用した例が報告されている。1台 の連続発振レーザーに位相同期された2台の光コムで $L_{\mathrm{a}}$ が1.5 mの装置を構成し，平均時間200 usにおいて精度 $3 \mu \mathrm{m}$ ，平均時間 $60 \mathrm{~ms}$ において精度 $5 \mathrm{~nm}$ が報告されてい る ${ }^{6)}$ 。また位相同期を行わなくてもコムの繰り返し周波 数を監視することで $L_{\mathrm{a}}$ を $1 \mathrm{~m}$ として平均時間 $140 \mu \mathrm{s} に お ~$ いて精度 $2 \mu \mathrm{m}$ ，平均時間 $20 \mathrm{~ms}$ において精度 $200 \mathrm{~nm}$ 達 成したとの報告もある ${ }^{13)}$ 。モード同期レーザーの構造 上, 変調型光コムほどの動的な周波数間隔切り替えは難 しいが, 物体光と参照光を入れ替えることで原理的に数 十 $\mathrm{km}$ の距離測定が可能とされる。これらの干渉計は干 渉検出器が1台で構成されており，ここで紹介した変調 型光コムの干渉計と構成が異なっている。一つの干渉信 号に参照面と測定対象からの反射信号が含まれるため, 両信号が重なる距離が計測の不感帯となる.

MSTAR と呼ばれる位相変調器型の二波長干涉計は, 二つの干渉検出器を持ち不感帯のない距離測定が可能で
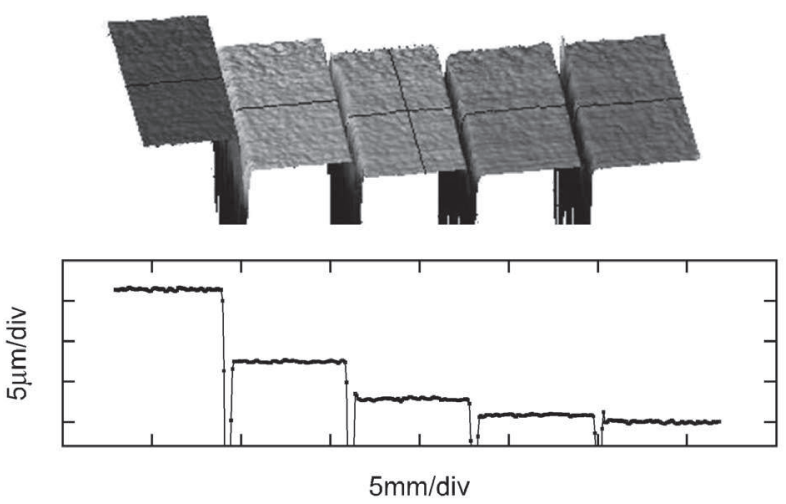

Fig. 7 Surface profile measurement of a step guage block Upper figure: three-dimensional display, lower figure: a cross section. Nominal steps are $10 \mu \mathrm{m}$, $5 \mu \mathrm{m}, 2 \mu \mathrm{m}, 1 \mu \mathrm{m}$ from left to right. 
ある点で変調型光コムの干涉計に類似している ドバンドの次数は \pm 1 次までであるが, $40 \mathrm{GHz}$ 帯の位相 変調器2台を使って $L_{\mathrm{a}}=1.875 \mathrm{~mm}$ の距離計を構成して計 測時間120 msにおいてレーザー光の半波長より高い $120 \mathrm{~nm}$ の精度を得ている。変調周波数を下げることで $L_{\mathrm{a}}$ の整数倍の距離を判別できるため, 原理的に数 $\mathrm{km} の$ 距 離測定も応用可能とされている.

モード同期レーザー型, MSTARともに人工衛星間な ど宇宙空間における位置決めが想定された研究であるの に対して，ここで紹介した変調型光コムの干渉計はその 制御性を生かした実用機器開発に重点が置かれている。

高精度と高速性を両立したことが特徴で, $L_{\mathrm{a}}=6 \mathrm{~mm}$ あるが, 距離5.2 mの計測精度が計測時間 $2 \mu \mathrm{s} て ゙ 0.4 \mu \mathrm{m}$, $1 \mathrm{~ms}$ で30 nmに達する。 $L_{\mathrm{a}}$ を超える距離測定であっても 電気的な周波数の切り替えのみで整数值を自動判別する システムとなっている. 今後は, $L_{\mathrm{a}}$ 以内の相対距離測定 の速度向上や絶対距離計測の繰り返し周波数 $1 \mathrm{kHz}$ の達 成が目標となる。

\section{7. まとめ}

変調型光コムを使う干渉計の原理, 距離計, 形状計測 機の性能について報告した。光強度変調の検出を利用す る従来型距離計に比べて大幅な速度と精度の向上が可能 となった．また複数光コムの干渉を使用する距離計の研 究動向を紹介した. どの方式もある平均時間以上では距
離計としての計測精度はレーザー光源の半波長に達して いる。長距離計測とレーザー干渉計によるナノメートル 計測が一連の計測として実行できる環境が整いつつあ る.

\section{参考文献}

1) M. Kourogi, K. Nakagawa, and M. Ohtsu: IEEE J. Quantum Electronics 29 (1993) 2693.

2) W. Estler, K. Edmundson, G. Peggs, and D. Parker: \{CIRP $\}$ Annals-Manufacturing Technology 51 (2002) 587.

3) K. Minoshima and H. Matsumoto: Appl. Opt. 39 (2000) 5512.

4) S.-J. Lee, B. Widiyatmoko, M. Kourogi, and M. Ohtsu: Jpn. J. Appl. Phys. 40 (2001) L878.

5) O. P. Lay, S. Dubovitsky, R. D. Peters, J. P. Burger, S.-W. Ahn, W. H. Steier, H. R. Fetterman, and Y. Chang: Opt. Lett. 28 (2003) 890.

6) I. Coddington, W. C. Swann, L. Nenadovic, and N. R. Newbury: Nature Photon. 3 (2009) 351

7) 今井一宏, 興梠 元伸：計測と制御 50 (2011) 112.

8) T. Kanemura, H. Kondo, E. Hoashi, S. Yoshihashi-Suzuki, N. Yamaoka, H. Horiike, T. Furukawa, Y. Hirakawa, and E. Wakai: Fusion Eng. Des. (2014) in press.

9) T. Kobayashi, T. Sueta, Y. Cho, and Y. Matsuo: Appl. Phys. Lett. 21 (1972) 341

10) K. Imai, B. Widiyatmoko, and M. Kourogi: Proc. 30th European Conference on Optical Communication (2004) p. We4. P. 044.

11) M. Kourogi, B. Widiyatomoko, Y. Takeuchi, and M. Ohtsu: IEEE J. Quantum Electronics 31 (1995) 2120.

12) P. E. Ciddor: Appl. Opt. 35 (1996) 1566.

13) T.-A. Liu, N. R. Newbury, and I. Coddington: Opt. Express 19 (2011) 18501.

\section{レーザーワード}

変調型光コム (EO-modulator-based optical frequency comb) 電気光学変調で生成される光コム. 大振幅変調や光共 振器による多重往復変調など, 単一周波数発振のレー ザー光に深い変調を加える方式で高次のサイドバンドを 発生してコム状スペクトルを得る. 光コムの中心周波数 と周波数間隔はそれぞれ入力レーザー周波数と変調周波 数に一致する. 周波数の高速切り替えや調整が容易であ
るなど，周波数や位相の制御性の良さが特徵である。変 調器の性能次第で変調周波数を $1 \mathrm{GHz}$ 以上に上げられる ため, 周波数間隔の広い光コムの生成に向いている。1 台のレーザー光源から周波数間隔の異なる複数の光コム を生成することも可能である，光差周波数測定，光波形 生成, 光コム干涉計測などへ応用される。(今井一宏) 